\title{
"Our day will come": \\ Histoire de Marie et Julien in the light of Les filles du feu
}

GARIN DOWD

In the 1970s Rivette consolidated the phase of experimentation announced in L'Amour fou (1969). Indeed it is also, paradoxically, the decade of what remains Rivette's biggest commercial and popular success - Céline et Julie vont en bateau (1974). However, the period is also characterised by impasse. Of the five films he completed during this period, Out 1 (1970) only received one public screening, Merry Go Round, though completed in 1978, was not released until 1983, and Noroît was not distributed theatrically. In particular, the abandonment of a planned tetralogy - of which Noroit (1976) would be part - must be considered in this context. "Les filles du feu" was the title of the tetralogy proposed to the Centre National de Cinématographie (CNC) in $1975 .{ }^{1}$ The commissioning body took the unprecedented step of agreeing to finance four films at once under the generous return on receipts policy which it administered. The project comprised four loosely-speaking genre films: Marie et Julien, the first named project, was to be a love story, the second, Duelle, would be a contribution to the genre of the fantastic, the third, Noroit, would be a western, while the final instalment was earmarked to be a musical comedy starring Anna Karina and Jean Marais. The fantastic film was made first, the western second. Hélène Frappat describes Marie et Julien as it was originally planned as follows: "histoire d'un homme qui vit seul dans le souvenir d'une femme qu'il a aimée et qui voit revenir une femme identique à l'autre, se met à vivre avec elle et découvre que c'est une morte". ${ }^{2}$ Rivette cast Leslie Caron (in what would have been her first role in a French film) in this variation on the Vertigo (1958) theme, while Albert Finney possessed in Rivette's estimation the right combination of foreignness and a good level of French to incarnate the role of Julien. ${ }^{3}$ Although his producer Stéphane Tchalgadjieff testifies to Rivette having shot two impressive scenes (which were subsequently lost at the laboratory) during the first two days on

\footnotetext{
${ }^{1}$ The title is taken from a collection of short stories by the poet Gérard de Nerval published in 1854.The original summary of the project was published in English in Jonathan Rosenbaum's collection to coincide with the 1977 National Film Theatre retrospective in London. Jacques Rivette, "For the Shooting of Les Filles du feu", in Jonathan Rosenbaum (ed.), Rivette: Texts and Interviews (London: BFI, 1977), pp. 89-90. ${ }^{2}$ Hélène Frappat, Jacques Rivette, secret compris (Paris: Cahiers du cinéma, 2001), p. 152.

${ }^{3}$ Caron's delight at being asked to star in her first French film (she had left France at the age of eighteen) is recorded in a newspaper interview in Boca Raton News (28 March 1975), p. 18. The extent of Finney's commitment to the project is suggested by his unheard-of proactive cost-saving decision to move to a smaller hotel for the shoot. Caron did play a role alongside one of Rivette's most frequently cast actors, Bulle Ogier, in Sérail, the 1976 film directed by one of Rivette's co-writers on Duelle and Noroit, Eduardo De Gregorio. The pretext of the film is the development of the characters played by Ogier and MarieFrance Pisier in the "film within a film" in Céline et Julie vont en bateau. The fact that Sérail even has its own French-speaking English actor, Corin Redgrave (hence the equivalent of Finney in Rivette's film), only serves to compound the Rivette link.
} 
set, the shoot came to an end when the director suffered a nervous breakdown. ${ }^{4}$ Caron was still eager to be involved when Rivette attempted to revive the film with Michel Piccoli, then Maurice Pialat (who turned it down) and even himself in the lead male role, but the project was eventually abandoned. Marie et Julien is nonetheless cited as an entry in Rivette's filmography (which Rivette himself is credited as having checked) in Hélène Frappat's 2001 book on the director. Frappat had at that point read the treatment re-discovered by the cinematographer on the tetralogy - William Lubchanksy ${ }^{5}$ - and reassembled by Rivette's original first assistant director Claire Denis, which led to the eventual revival of the project in $2002 .{ }^{6}$ The retrieval of the film from oblivion provides a useful point of entry into some topics of pertinence to the larger contexts of Rivette's career. In particular, with regard to the specificity both of the reanimated project originally titled Marie et Julien and the two completed films, the incomplete status of the tetralogy (which eventually came to bear the title Scènes de la vie parallèle) must inform on some level the appraisal of the films in their full contextual framework. Moreover, the trope of the incomplete work, or of the work defined by its falling short of the status of work, is at play in other ways in these films and their late supplement.

\section{Contingency as an element of a mise-en-scène désœuvrée}

Commenting on the fact that many of Rivette's films exist in different versions, and in an important sense are therefore identified by their author as always provisional, Jean-Pierre Samocki suggests that this multivalence "[met] en crise l'unité de la fiction par les variations de la durée, de partir de la cohésion d'origine pour inventer un nouveau rythme: entre expansion et contraction, accéleration du drame ou primauté accordée à la liberté des acteurs". ${ }^{7}$ Samocki's 2009 appraisal is a summation looking back at principles which Rivette has unstintingly pursued throughout his career, even before he was able to give them shape on film. While Rivette the filmmaker is of course famed for his emphasis on film-making as a process and for the stimulation his methods provide for contingency to invade this process, this is an approach which is there in embryonic form in his early critical writings. To take but one example: in his 1954 Cahiers du cinéma review of Preminger's Angel Face (1952), following a striking definition of mise en scène which is a template for some of his later reflections on his own work, he insists that Preminger's mise en scène is a commitment to contingency and

\footnotetext{
${ }^{4}$ Stéphane Tchalgadjieff cited in Frappat, Jacques Rivette, secret compris, p. 149. Frappat attempted to find the footage from the abandoned shoot. She recounts this and other details in connection with the abandoned film (among which the intriguing detail that Marguerite Duras wanted to continue in Rivette's place) in an analysis included in the French DVD release of Histoire de Marie et Julien (Arte, 2004).

${ }^{5}$ Lubchansky and the original editor Nicole Lubchansky were to work on all the films in the tetralogy. This continuity across the span of 28 years between "Les filles du feu"/"Scènes de la vie parallèle" and Histoire de Marie et Julien is also present in a small but significant manner in the casting of Nicole Garcia, who plays the part of a friend of Marie in Histoire de Marie et Julien and of the quintessentially ambiguous Jeanne/Elsa in Duelle.

${ }^{6}$ The working script outline rediscovered by Lubchansky and reassembled by Claire Denis was published in a short collection: Jacques Rivette, Trois films fantômes de Jacques Rivette (Paris: Cahiers du cinéma, 2002). The 1975 working script details 51 scenes which, despite the many changes in emphasis and the additional material and characters, are recognisable in the 2003 film.

7 Jean-Pierre Samocki, "Jacques Rivette: après l'absolu”, Trafic, 72 (2009), 27-55 (p. 27).
} 
chance within the controlled experiment of an overarching construct: ${ }^{8}$

The film is not so much an end as a means. Its unpredictability attracts him, the chance discoveries that mean things cannot go according to plan, on-the-spot improvisation that is born of a fortunate moment and dedicated to the fleeting essence of a place or person. If Preminger had to be defined in one word, it would be metteur en scène. In the midst of a dramatic space created by human encounters he would exploit to its limit the cinema's ability to capture the fortuitous (but a fortuity that is willed), to record the accidental (but the accidental that is created) through the closeness and sharpness of the look. The relationships of the characters create a closed circuit of exchanges, where nothing makes an appeal to the viewer. ${ }^{9}$

The experiments that provide such stimulus in Rivette's work include collaboration with actors in writing the script, the use of the theatre-cinema conjunction/disjuncture, and other localised and often improvised and pragmatic innovations during the tournage. The notes for the tetralogy considered as a whole in explaining the rationale for making four films at the same time, highlight Rivette's search for conditions that would serve to nurture the "fortunate moment" and "circuit of exchanges" (as described in the review of Angel Face): "it is the only way of being able to establish a specific 'circulation' between these films with certain characters and certain décors reappearing from one to another under different lights, contradictory or complementary". ${ }^{10}$ The identity of the encompassing work "Les filles du feu" would, then, reside in resonant and dissonant relations between the films. Rivette is interested both in the relations that would serve to complete and confirm as well as those which would keep open and render ambiguous: "how the interplay of reciprocal influences from the four productions would function, the interactions between the casts, their attitudes, their relationships - and what might be modified (accentuated, influenced, transformed) by this interplay". ${ }^{11}$ This interest in de-stabilisation and disorientation by virtue of interplay is complemented in Rivette's outline with regard to the individual shooting plans. These would be broken down into fifteen individual units or "block sequences" and each of these blocks would be "subjected to a method designed to break down not only traditional dramatic techniques but also the more recent conventions of improvisation with all the prolixities and clichés it entails [...] and to establish an écriture based on actions, movements, attitudes, the actor's 'gestural', in other words". ${ }^{12}$ Rivette's interest in experimenting with the bodies of actors as a starting-point is here at the core of the envisaged mise en scène, which, rather than a Greg Tolland-style commitment to depth of field as such on its own terms, is a possibility for

\footnotetext{
8 "Preminger believes first in mise en scène, the creation of a precise complex of sets and characters, a network of relationships, an architecture of connections, an animated complex that seems suspended in space". Jacques Rivette, "L'Essentiel”, Cahiers du cinéma, 32 (February 1954), 42-45, trans. Liz Heron, in Jim Hillier (ed.), Cahiers du cinéma, The 1950s: Neo-realism, Hollywood, the New Wave (Cambridge, MA: Harvard University Press, 1985), pp 130-135 (p.134).

${ }^{9}$ Rivette, "L'Essentiel", p. 134.

${ }^{10}$ Rivette, "For the shooting of Les Filles du feu", p. 89.

11 Ibid.

${ }^{12} \mathrm{Ibid}$. The idioms of post-structuralism are very much in evidence in Rivette's thought in this period.
} 
encountering "the movement of bodies, their counterpoint, their inscription within the screen space". ${ }^{13}$ The third formal operator designed to effectuate the pressure of contingency to be felt in the individual films operated across the blocks and took the shape of the planned presence on screen of musicians playing live. It was this innovation that would, in Rivette's mind, make definitive the "crossing of the frontier which separates traditional acting from the one we are looking for". This conjunction would serve to create another mode of mutual transformation, the improvisation of the musicians being channelled by the actors, who in turn would have their own performances altered by the live music. ${ }^{14}$ To cite just two examples, one going in each direction of the mutual transformation: in the dance studio scene in Duelle between Leni (Juliet Berto) and Elsa/Jeanne (Nicole Garcia), Jean Wiener sits facing the piano at the back of the set with his head turned towards the actors waiting to commence playing in response to their movements within the set; in a scene in Viva's room, Bulle Ogier taps out the rhythm of Wiener's improvised playing with her cane as she discusses tactics with her earthly accomplice.

The three principles of a mise en scène of contingency outlined above in Rivette's plans would be progressively accentuated throughout the tetralogy. ${ }^{15}$ They would open in the first film, Marie et Julien. Here there would be an element of genre conformity, Rivette stating that this film would still follow "the rules of romantic fiction". By contrast, the fourth film, which was to star Anna Karina, would see "the various aspects [...] driven to paroxysm". ${ }^{16}$

The two films completed from the "Les filles du feu" project, Duelle and Noroit, contain elements of Rivette's signature désœuvrement. As Ishaghpour remarks, in Rivette "I'œuvre comme finalité sans fin s'approche du manque de finalité". ${ }^{17}$ The finalité sans fin (another way in which one might characterise the trope of désœuvrement), containing vestiges of a Bazinian faith in the idea of montage interdit but without the tendencies towards organic wholeness of Bazin, is partly pursued through Rivette's commitment to collaboration. In his manner of "conspiring", as Rivette puts it, with a troupe of actors, he also seeks to exploit them individually and collectively as forces of contingency.

It is in this context that his use of theatre can be understood. While theatre as such is absent from both Duelle and Histoire de Marie et Julien, in the sense in which it is present in, say, Paris nous appartient (1961), La Bande des quatre (1989) and the later Va savoir (2001), to

\footnotetext{
${ }^{13}$ Rivette, "For the Shooting of Les Filles du feu", p. 89. Rivette had described Céline et Julie vont en bateau as looking very much like an RKO production from the 1950s under "the Gregg Toland influence", in Jonathan Rosenbaum and Gilbert Adair, "Phantom Interviewers over Rivette", Film Comment (September 1974), p. 20. Duelle would subsequently be described by de Gregorio as a film of pure mise en scène (cited in Frappat, p. 152), while Serge Daney's first question to Rivette in the documentary portrait Le Veilleur (1990) concerns the distance at which he tends to film his actors.

${ }^{14}$ For an account of the use of live music see François Thomas, "Les films parallèles: Musique et sons directs", in Daniela Guiffreda (ed.), Jacques Rivette: La Règle du jeu (Turin: Centre Culturel Français de Turin/Museo Nazionale del Cinema di Torino, no date), pp. 165-169.

${ }^{15}$ For Youssef Ishaghpour they amount to a utopian conception of tournage and reflect a continuing adherence to a Bazinian faith in the ontology of the cinematographic image, Cinéma contemporain: De ce côté du miroir (Paris: Éditions de la Différence, 1986), pp. 211-232 (p. 217).

${ }^{16}$ Rivette, "For the Shooting of Les Filles du feu", p. 90.

${ }^{17}$ Ishaghpour, p. 221.
} 
name but three more obvious interpenetrations of the cinematographic and the theatrical, aspects of related types of stage performance are nonetheless present or evoked in both films. Duelle features Jean Babilée, for whom Cocteau had written the ballet Le jeune homme et la mort (1946), whose graceful physical acting suggests his field of expertise has strayed on to a film set. ${ }^{18}$ Noroit is closer to the theatre films in having as one of its sources Tourneur's The Revenger's Tragedy which serves to give a focused outlet to the general foregrounding of performance, simulation and travesti within the castle. As this element of the film is described by Jonathan Rosenbaum:

without the narrative-illusionist pretext of the rehearsal to "place" it, apart from a few perverse instances that work more as displacements: Morag's murder of Regina, which serves as "rehearsal" for its re-enactment by Erika and Morag before Giulia and her court; the rehearsed swordfight between Ludovico (Larrio Ekson) and Jacob (Humbert Balsan), merging imperceptibly along with the music into a performance staged to confound Erika. ${ }^{19}$

The rehearsal element is key, however, in terms of continuity with the other films with a more direct theatrical element, and it is the use of direct sound with music played live by musicians appearing on the set as actors but not quite, as actors whose presence breaks the integrity of the screen space in a manner predicted by Rivette in his "Les Filles du feu" text. ${ }^{20}$ Given the outline of progressive accentuation of the principles of mise en scène identified by Rivette in the "Les filles du feu" proposal, it is fitting that Histoire de Marie et Julien should be more traditional in form than Duelle or Noroît. The film opens with a scene which features a low-angle shot of a rather stiff-looking Marie (Emmanuelle Béart) striding through a park. This is subsequently revealed to represent the dream of Julien (Jerzy Radziwilowicz) as he sleeps slumped over a cafe table. ${ }^{21}$ Momentary intrusions of the fantastic are limited to Béart's verbal delivery, which on occasion is in the declarative and trance-like mode reminiscent of some of Cocteau's films (such as Orphée [1950]) favoured by Rivette in Duelle. Such instances are identified clearly in the film as moments when she has become a mouthpiece for the supernatural. In his interview for the DVD release Rivette also explains that certain phrases were delivered in a deliberately artificial manner because they were in the original working notes; in the revived project they functioned like magic phrases but also as anachronous parentheses. There is no attempt to retain other aspects of the original principles of the mise en scène: no live music, and a reduced amount of experimental play with the actor and the

\footnotetext{
${ }^{18}$ The opening sequence in the empty hotel played between Lucie (Hermine Karagheuz) and (Pierrot) Babilée (at the time of the film an acclaimed dancer and choreographer) and the blue-tinged monochrome hallway scene late in the film between him and Viva (Bulle Ogier) are especially balletic.

${ }^{19}$ Rosenbaum, Film: The Front Line (Denver: Arden Press, 1983), pp. 162-74, p. 167.

${ }^{20}$ As Alain Ménil has commented, rehearsal is perhaps the component of theatre which is most withdrawn from all cinematographic existence: it is not mechanically reproducible. "Mesure pour mesure: Théâtre et cinéma chez Jacques Rivette", Études cinématographiques, 63 (1998), 67-96 (p. 70).

${ }^{21}$ In her interview for the DVD Béart explains that Rivette had deliberately made her uneasy by dressing her character for the filming of the opening scene in a white trouser suit somewhat at odds with the rest of the costumes planned for her character.
} 
gesture. This aspect of the ambitions outlined in the "Les filles du feu" text would now be obsolete as far as Rivette is concerned: he is no longer, in 2003, attempting to "discover a new approach to acting in the cinema", since his explorations in this regard continued despite the abandonment of the tetralogy. Little is retained, then, on a formal level of what I have suggested may be called the mise en scène descuvrée of the tetralogy. ${ }^{22}$

\section{Rivette in the 1970s}

In the 1970s Rivette, by his own admission, became disengaged from politics. Duelle and Noroit belong to a period in Rivette's œuvre which in part may be characterised as a retreat into genre. The films are playful and relentlessly artificial, so much so that Duelle would later be one of the three films identified as an Urtext for the cinéma du look with what some commentators have identified as its neo-baroque scopic regime of falsity, duplication and multiplication. ${ }^{23}$ As Rosenbaum describes Duelle: "breaks in legibility, ruptures of tone, momentary disorientations or encumbrances that we usually skip over or skim when we encounter them on a printed page. In Duelle we must pass through them."24

To say this however is not to underestimate the continuity with certain strands in Rivette's work up until this point. Conspiracy is one such strand. Before any consideration of the genre of the fantastic, the first genre to be considered is the one Rivette invented, namely what has been called the genre of "consipracy without conspirators", a genre which is closely identified by some Rivette specialists (notably Frappat) with the question of modernity ${ }^{25}$ : "[L]a modernité consiste à inventer des complots d'ou toute intention a disparu". ${ }^{26}$ Rivette's films are inflected in complex ways, both by genre and by politics, whether in the context of a specific regime (Giscard's 1970s) or an event like May '68. On this aspect of Rivette, Deleuze has commented: "And if the political, judicial, and police conspiracies weighing on us are enough to show that the real world has become a bad movie, then it is cinema's job to give us a piece of reality, a piece of the world." ${ }^{27}$ It is in this sense that Rivette's films may be said to be political. For the Rivette of 1968 all films are political and, while he reveals what for him is the impossibility of the revolutionary film which would mobilise people, he nonetheless holds out

22 Nonetheless working with Rivette continues to present enormous technical challenges. As cinematographer William Lubchansky explains, complex camera movements and lighting arrangements are often required on the spot in response to decisions made there and then. He cites the example of a very difficult tracking shot and zoom combination (the only use of a zoom in all the films he made with Rivette, he asserts) in the scene designed to emphasise Marie's otherwordliness (or that portion of her which is otherwordly) where Marie and Julien lie in bed and Marie gets up to visit the suicide room.

${ }^{23}$ Notably Raphaël Bassan, "Trois néobaroques français", Revue du cinéma, 449 (1989), 44-50.

24 "Duelle: Notes on a First Viewing", Film Comment, September-October 1976.

${ }^{25}$ For Evelyne Jardonnet genre is merely a pretext for refashioning the location and imbuing it with the effects of a haunting by the genre as spectre: "Périodiquement, l'œuvre de Rivette effectue quelques incursions dans le cinéma de genre. Dans Paris nous appartient, et Duelle, la modification de l'espace parisien consitutue l'un des enjeux majeurs du recyclage intertextuel". Jardonnet, Poétique de la singularité au cinéma: Une lecture croisée de Maurice Pialat et Jacques Rivette (Paris: L'Harmattan, 2006), p. 221.

${ }^{26}$ Frappat, Jacques Rivette, secret compris, p. 213.

${ }^{27}$ Gilles Deleuze, "Rivette's Three Circles", in Two Regimes of Madness: Texts and Interviews 1975-1995, trans. Ames Hodges and Mike Taormina (New York: Semiotext(e), 2006), pp. 355-358 (p. 357). 
hope for a revolutionary cinema that would succeed in aesthetic terms, citing Glauber Rocha in this respect. ${ }^{28}$ It is in this context that his representation of Paris is to be understood: Paris as an oneiric space at once empty and full of potentialities and virtualities. As Evelyne Jardonnet comments with regard to Rivette's use of Parisian parks in his films: "Rivette réactive le potentiel fantasmagorique de ces parcs décelé par les surréalistes ou quelques-uns de leurs continuateurs." 29 These locations form part of what Anne-Marie Faux has identified as "[I]e sujet de la fiction rivettienne, on le sait, on le voit, c'est d'abord le lieu: labyrinthes, passages, réseaux, secrets qui naviguent entre la rue, la scène, la maison, les personnages". ${ }^{30}$ Conspiracy and the city are interlinked in the shape of intrigues which lack linear progression but which instead confront impasse and detour.

\section{Genres and intertexts}

Alluding to his breakdown on the set of Marie et Julien, Rivette explains in the DVD interview that, in starting the project again, he wished to begin with a blank slate. But he also shows how, in re-reading the original notes, "chalk marks" and the traces left by the "duster" remained visible on the "blackboard". Some sentences were incomprehensible; he did not, nor could any one else remember what "le geste interdit" referred to in the script was. ${ }^{31}$ In the interview Rivette is pressed on a particular point concerning the revenant. He insists that the women of Duelle are not revenants; they are from another planet; they are goddesses. He also states that the distinction between the nocturnal Madame X (Anne Brochet) - who is being blackmailed in the film's subplot by Julien - and the diurnal Béart (which distinction would reprise another element of Duelle and Noroit), while not intended, is nonetheless not invalid. Rivette does however confirm that the revived project, with Pascal Bonitzer and Christine Laurent as writers, returned to the original sources for the tetralogy, namely La Femme celte by Markale and Le Carnaval by Claude Gaignebet, both of which had recently been published. ${ }^{32}$ From the Markale source the basic idea of a woman taking possession of her future lover is retained and amplified. ${ }^{33}$ As Markale describes the archetypal narrative at the core of its most famous literary manifestation:

La femme, dès son apparition au milieu d'un paysage, métamorphose l'aspect de ce paysage, et par voie de conséquence, l'observateur du paysage lui-même, puisqu'il appartient de fait à l'univers au centre duquel évolue l'être féminin. Ainsi l'observateur

\footnotetext{
28 "Time Overflowing", in Rosenbaum, Rivette: Texts and Interviews, pp. 9-38 (p. 33).

${ }^{29}$ Jardonnet, Poétique de la singularité au cinéma, p. 232.

${ }^{30}$ Anne-Marie Faux, "Une bien discrète crapule", in Giuffrida (ed.), Jacques Rivette: La Règle du jeu, pp. 195-197 (p. 195). Rivette had himself identified the labyrinth of interconnected spaces with selections of routes to be made in "Time Overflowing", p. 28.

${ }^{31}$ Trois films fantômes de Jacques Rivette, p. 104.

${ }^{32}$ Claude Gaignebet and Marie-Claude Florentin, Le Carnaval (Paris: Payot, 1974) is the source for the theme of the quarantaine which is replicated in the two films from 1975. The idea of the 40 days or one and a half lunar cycles is in evidence in the draft script notes and has largely a spectral presence in Histoire thanks to its links with the two earlier films.

${ }^{33}$ Jean Markale, La Femme celte: mythe et sociologie (Paris: Payot, 1987; originally published 1972).
} 
ne sera jamais le même après qu'il aura vu son paysage habituel transformé, et luimême ne s'appartiendra jamais plus entièrement, puisque la femme, insensiblement, aura assuré sa domination sur le paysage dont il fait partie. ${ }^{34}$

In addition there is a correlation between the commanding woman's capacity to possess and the man's capacity to perceive her. Further to this mythological template, which is replicated in Histoire de Marie et Julien (albeit in a space reduced from a landscape to a house), on the suggestion of Christine Laurent the idea of the geis (curse) central to Celtic mythology is added. ${ }^{35}$ According to Markale's account:

C'est une sorte d'interdit, jeté à la suite de certaines circonstances sur un individu et qui marque définitivement cet individu. Transgresser le geis, c'est s'exposer à de graves ennuis et finalement à une mort non seulement douleureuse mais odieuse. ${ }^{36}$

Transgression will lead to a deep shame which results in social exclusion. The geis is more often than not delivered by women, as is the case with Gráinne (in the legend Tóraigheacht Dhíarmuida agus Ghráinne [The Pursuit of Diarmuid and Gráinne], generally recognised as the source for the story of Tristan and Iseult), whose love for Diarmuid is evoked in the lines delivered by Béart in Histoire. ${ }^{37}$ In the Irish legends discussed by Markale the geis is often supplanted and superseded by further geisa, thus making it impossible for the man under its yoke not to break at least one or some of them. It may be speculated that in seeking an answer to what he may have originally meant by "ne pas oublier le geste interdit", Rivette and his cowriters found inspiration in the general ambiance of the forbidden in these legends. Hence in employing as a last resort the forbidden gesture (hands facing outward crossed over the face) taught her by the deceased sister of Madam X, the film's other revenant, Marie curses herself to staying in the land of the living and consigns Julien to no longer loving her. This mythological aspect of the original premise is strengthened - if, conversely, other elements of the original found themselves diminished - in the 2003 film, in the Irish words spoken by Marie as she repeats a version of the preparation for her suicide standing on the stepladder which she used for her death at her own hand. ${ }^{38}$ The "incantation magique" is central to legends featuring the geis. As Rivette confirms in interview, the original couple was destined for a bad end, like Diarmuid and Gráinne and like their "descendants" Tristan and Iseult. Even if the final scene is laden with morbidity and puts to an end the relationship of the couple as they themselves have experienced it, the ending nonetheless evokes the idea of rebirth central to the film's sources in legend. The closing title music, "Our day will come" by Blossom Dearie, serves to emphasise the

\footnotetext{
${ }^{34}$ Markale, pp. 293-294.

${ }^{35}$ The power of the geis is inherited from former gynaecocratic cultures influenced by druidism (Markale, p. 313). This explains the replacement in the story of Tristan and Iseult of the geis by the magic aphrodisiac potion, a trope more palatable to Christian belief.

${ }^{36}$ Markale, pp. 311-312.

${ }^{37}$ Rivette confirms in the DVD interview this introduction of the idea of the geis.

${ }^{38}$ The actual suicide, Julien learns in the course of his investigation, involves her binding her own hands, slashing her own face and hanging herself in order to incriminate her lover.
} 
final scene, with Marie perhaps now restored to a kind of mortal presence on earth but at the price of the loss of any memory of their relationship. This is foreshadowed in Marie's Irish recitation.

The final scenes also reintroduce elements which recall Duelle. There the sought-after diamond, when mixed with human blood, annihilates the goddesses. In Histoire tears mixed with the scar of the cut from which no blood has issued result in the traversal of the revenant ostensibly into the world of mortals. At this point the story of Marie and Julien may begin again, given time as Marie informs Julien. The story, then, has taken place, but in another sense is still potentially to come. The lovers' common existence is sundered by the fact of their common existence in the possible world opened by the return of the revenant. ${ }^{39}$ The repetition empties the present. The repetition empties the present; it voids the story itself which becomes the unknowable rehearsal for a possible future life together in which this time she will be mortal (and mortal again, but for the first time as far as Julien is concerned) but without the memory on his part of his role to play. He will have to learn as if for the first time. In this ending Rivette, having signalled his following the lesson of Cocteau (ensuring that the set had nothing of the fantastic), in terms of mise-en-scène, after the necessary duration, which in Todorov's terms defines the fantastic genre, pushes the film to the side of the marvellous as opposed to the uncanny. 40

\section{Rivette's house}

What is a revenant? For Frappat it is a woman who comes back because she has not been born. ${ }^{41}$ In this respect "Scènes de la vie parallèle" "se déroule dans un monde à l'écart, une quarantaine gouvernée par la loi du secret". ${ }^{42}$ The woman who comes back " $n$ 'a pas d'origines; surgie de l'espace, hors du temps, elle voudrait durer". ${ }^{43}$ It is clear why Rivette is so insistent to his interlocutor on the specificity of the revenant and the important distinction which must be made between it and various forms of ghostly haunting. The revenant, he explains, has not crossed to the other side of the frontier of life and death. The revenant comes back from the borders. Rivette's use of point of view in Marie et Julien serves to underline this aspect of the revenant. The first dream sequence - which is described by Rivette as a kind of homage to 1970s films which might begin with a dream sequence (he cites Buñuel as an example) - from the point of view of Julien displays his oneiric conjuring of Marie which prefigures their later encounter. By means of initial sections presented from the point of view of Julien followed by the progressive integration of the point of view of Marie and culminating in her domination of point of view at the end, Rivette shows the phenomenon of haunting which gives us the

\footnotetext{
${ }^{39}$ Samocki has read this in terms of a negotiation of the theme of the absolute: "un même désir pour deux chairs differentes; une meme condition humaine balafrée par deux désirs qui à la fois se réclament et s'excluent, deux puissances qui s'attirent et refusent de se condemner [...] Ce désir de totalité, qui est en fait tout simplement dans le désir de Julien un désir de présence, devient alors, bien malgrée lui, un désir irréperable d'absolu". Samocki, "Jacques Rivette: après l'absolu", p. 31.

40 Tzvetan Todorov, The Fantastic: A Structural Approach to a Literary Genre, trans. Richard Howard (Ithaca: Cornell University Press, 1975), p. 40.

${ }^{41}$ Frappat, p. 218.

${ }^{42}$ Frappat, p. 219.

${ }^{43}$ Frappat, p. 219.
} 
reversibility of heimlich and unheimlich (symbolised most powerfully in the replicated blue room). The famed Freudian account is linked by Avital Ronnel to an aspect of hospitality which is very pertinent to the universe of Rivette. A haunt, she points out, is also a place one frequents. ${ }^{44}$ The supernatural does not feature to any great extent in Rivette's work after the 1970s films, although the sense of a fantastic not exhausted by the idea of the supernatural is still evident in L'Amour par terre (1984) and Le Pont du nord (1982), while the idea of the revenant is there in Va savoir (2001) and Secret défense (1998). His producer for the tetralogy Stéphane Tchalgadjieff recounts how Rivette used Val Lewton's films (those directed by Tourneur not least, but also The Seventh Victim [1943], which was used specifically in preparing for Duelle) as reference points in preparing Les filles $d u$ feu. Traces of the influence of The Seventh Victim are still present in the revived version of the planned 1975 film. In the Mark Robson film the suicide room in the boarding house above the restaurant is presented both spatially and in the narrative as an exceptional space, with only a chair and, we later learn, a noose. It is in some ways a virtual and anachronous space dedicated to the future and to the tocome, which is for the troubled sister equivalent to her own annihilation. But being given over to pre-scripted action, the room is also the place where the past presses forward. In Histoire de Marie et Julien the room in Julien's house - a replica of the suicide room in her apartment fashioned by Marie as revenant - is the repository of the immediate past, a locus of mourning for Julien by virtue of a projected fantasy of the retrieved Marie, and the indeterminate zone of the embodied Marie as revenant. The revenant returns from the past to hollow out (and to perform a hauntology of) the present - the home, the heim. As Samocki argues with regard to one scene in particular, the condition of phantom which the scenario imposes is refused by the mise en scène. ${ }^{45}$ When Marie has used the forbidden gesture, she briefly adopts a ghostly status and can no longer be seen by the other characters, whereas the film viewer continues to see her, and her together with them, as before.

The house, more generally in Rivette, is the site for returns, for turns, for stories to be tried out, for forking paths to be established. The house is any site for fiction, recounting, performing: the home is the set. Insofar as they offer themselves as stages, the house and the room in Rivette are always workshops, film sets or (in continuity with the theatrical dimension discussed above) rehearsal spaces.

The ultimate shelter for Rivette's tournage films is the film as work. In one example of déscuvrement in his book L'Espace littéraire, Maurice Blanchot characterises the interaction of the artist and the work in progress which cannot be finished, or refuses to be finished, as initiating a moment of exclusion and separation. ${ }^{46}$ The artist finds himself cast out of the circle of the work. Yet he is also held in its borders by the unfinished work which refuses to release him. On the one hand it is impossible to turn away and on the other it is impossible to abide with the work. What is required of the author is a half-life, a homeless abeyance in an

\footnotetext{
${ }^{44}$ Avital Ronell, Dictations: On Haunted Writing (Lincoln and London: University of Nebraska Press, 1993), p. 6. That having been said, Rivette's insistence on the fact that Marie is a revenant, and is therefore materially and corporeally present, would make her a participant in an economy quite distinct from a Derridean ghost dance.

${ }^{45}$ Samocki, "Jacques Rivette: après l'absolu", p. 31.

${ }^{46}$ Maurice Blanchot, L’Espace littéraire (Paris: Gallimard, 1955), pp. 56-62.
} 
"enclave". The enclave - which finds many manifestations in the récits of Blanchot - does not really support life, being airless and without light, as Blanchot explains. ${ }^{47}$ Nor is it stationary: the enclave is torment itself and takes the form of an errant circumnavigation of the zone of exclusion-inclusion.

Great works, whose greatness surpasses the splendour of their creators, have, Blanchot suggests, a perceptible point which is the mark of the moment when their creators decided that if they did not leave the work at that point they might never return to the light. ${ }^{48}$ Others bear the wounds of successive attempts and reattempts. It comes down to a question of what one does with these ruined works: restore them or leave them to their abandonment (Blanchot prefers the latter). Rivette's return to Histoire de Marie et Julien could never undo the effects of the abandonment of the tetralogy; indeed it does not seem to be designed to achieve this, nor could it ever do anything other than underline the fact that, not only can the fourth film never be made, but also, in an important sense (signalled emphatically by the decision not to include any mention of "Scènes de la vie parallèle" in the title), neither can Marie et Julien be made one of the "scènes de la vie parallèle". Rather, the return serves to remind us of the unique experiment of Rivette's tetralogy and of the richness of his output, both realised and spectral, in the 1970s. Phantoms and the material world combine in Histoire de Marie et Julien. The making of the film completes the abandonment of what one imagines will remain, because it could only remain, one of the great unfinished projects of one of the great film directors.

\footnotetext{
${ }^{47}$ Blanchot, p. 59.

${ }^{48}$ Blanchot, p. 59.
} 
